\title{
DIE TAAK EN METODES VAN DIE MUSIEK- OPVOEDING AAN S.A. UNIVERSITEITE.
}

In 'n vorige artikel het ek verskillende aspekte van die Musiekopvoeding in Suid-Afrika oorsigtelik behandel en onder andere verwys na die dringende noodsaaklikheid van 'n sistematiese, gebalanseerde opleiding van 'n nuwe Musiekonderwyserstipc.' Ek verwelkom die geleentheid om tans nader in te gaan op die taak en metodes van sodanige opleiding aan 'n universitêre Musiekdepartement.' Dit word gedoen in die vaste oortuiging dat uitstippeling van die musiekterrein en definitiewe stellingname ten opsigte van die musiekopvoeding noodsaaklik is, enersyds om optimale werkprestasie van dosente en studente te bewerkstellig, andersyds om die leemte wat daar bestaan aan 'n geformuleerde musiekbeleid in die opvoeding te help aansuiwer. Dit is te meer noodsaaklik omdat Musiek, as betreklike nuweling onder die humaniora, en as eersteling onder die Skone Kunste om aan Suid-Afrikaanse Universitcite opgeneem te word, by alle welwillendheid, tog onvermydelik blootgestel is aan wanbegrip en vooroordeel.

In ooreenstemming met die dubbele hoedanigheid van die vak as 'n kuns en 'n wetenskap, word 'n verdeling van die opvoedkundige bestek in twee basiese departemente voorgestel nl., Musiekwetenskap en Praktiese Musiek, wat verskillende oogmerke en metodes het, maar uit die aard van die saak in noue voeling met mekaar moet bly. Ons wil nie 'n musikus vorm met ' $n$ gesplete of eensydige musikale persoonlikheid, met kompartementele opvattings oor die kuns nie, maar 'n twee-in-een, 'n kunstenaarsof opvoedkundige tipe wat kenner en liefhebber tegelyk is. Weliswaar kom hierdie strewe in die lig van ervaring byna oral waar musici vergader, idealisties voor. Wrywinglose koördinering van kunstenaarstemperament en wetenskaplike metodes is sekerlik 'n moeilike ideaal om te verwesenlik. Die gebruiklike Europese oplossing is 'n skciding van die funksies in aparte liggame, Hochschule of Konservatorium aan die een kant, die universiteitsdepartement vir Musiekwetenskap aan die ander kant. Die gevaar van sodanige verdeling is dat daar twee "musiekstande" ontwikkel wat nogal

1) Hervorming van die Musiekopvoeding in Suid-Afrika Dic Veteraan Deel XVIII, 1953, bls. 21-26.

2) Die gedagtes uitgespreek in hierdie artikel is in die eerste instansie die vrug van ervaring opgedoen in die organisasie van die Musiekdepartemente aan die P.U. vir C.H.O., die eerste inrigting om twee afsonderlike leerstocle vir Musiek in te stel. 
heel dikwels antagonisties teenoor mekaar staan: die wat ken maar weining kan en die wat kan maar weinig ken. 'n Nuwe land met 'n ontluikende, eie kulturele lewe staan in die gelukkige geleentheid om uit die geskiedenis en ervaringsrykdom van die ou lande die beste te haal en in diens van eie konstruktiewe arbeid te stel. Meer nog, heersende omstandighede en behoeftes dwing ons om 'n eie rigting op te gaan en 'n middeweg te probeer vind, wat in die tradisioneel en histories gebonde Europese lande nouliks meer moontlik is. Die snelle tempo van ontwikkeling in Suid-Afrika vereis, ook van diegene belas met die opleiding van musici, realistiese benadering en aktiewe aanpassing. Laat ons die feit in die gesig staar: beide hooggeleerde musiekwetenskaplikes sowel as hoogontwikkelde musiekvoordragkunstenaars is op hierdie stadium van ons ontwikkeling 'n luukse wat ons moeilik kan bekostig. Hulle bestaansmoontlikhede is gering. Daarteenoor staan 'n skreiende behoefte aan opvoedkundige musici dwarsdeur die land, mense wat deur aanleg en opleiding bevoeg is om die talryke vakatures te vul en Musiek as kuns en as kennis aan die opkomende geslag oor te dra. Ons Musiekopvoeding het in die groef beland van 'n uitheemse, eensydige sisteem wat totaal ontaard en Musiek verneder het tot klaviergetokkel in die dreigende skaduwee van jaarlikse eksamens. Van die magtige vormingspotensiaal van die toonkuns as middel tot Godsverheerliking, as sosiale funksie van die homo ludens, as geestelike en sosiale dissipline vir die kind en as skoonheidsbelewenis kom daar, helaas, weinig tereg. Ek hoef hier slegs te verwys na resulterende verskynsels soos die snelle afname van belangstelling in Musiek vanaf die vierde jaar nadat die kind begin het, die swak gehalte van ons kerkmusiek, die kwynende bestaan van kore en orkeste, die sporadiese en eentonige gehalte van ons konsertbedrywighede en die woekering van 'n soort Musiek wat wel die vermoë het om bewegingsreflekse uit te lok, maar die skoonheidsin afstomp, 'n soort van musikale pornografie wat ongelukkig gereeld in veldtogte teen onsedelikheid misgesien word.

Samevattend: ons behoefte gaan na 'n tipe van opvoedkundige musikus wat benewens aanlegr en gocie wil, beskik oor voldoende artistieke en wetenskaplike vorming om, deur teëwerking van wanpraktyke en die ver knndiging van 'n goedgefundeerde musiekbeskouing in onderrig en in die musiekbeoefening in Kerk en maatskappy, hervormend en bouend die status en vormingspotensiaal van die toonkuns in Suid-Afrika te verhoog.

Die opleiding van sodanige musici is die taak van die universiteite wat oor musiekdepartemente beskik. In breë trekke het alle sodanige inrigtings hulle opleiding gevorm langs die twee weë hierbo genoem, maar met soms belangrike verskille ten opsigte van kursusduur, kursusindeling en interne organisasie. Die vraag ontstaan of die tyd nie nou ryp is viı 
onderlinge samesprekings om definitiewe riglyne en doelstellings sowel as groter eenheid in die opleiding vas te stel nie. Daar bestaan 'n dringende behoefte aan 'n gemeenskaplike program van aksie om die musiekopvoeding in gesonder en meer progressiewe bane te lei. Verder is daar aktuele vraagstukke soos die verlammende gevolge van die Holloway-kommissie se bevinding, dat Praktiese Musiek nie as onderdeel van die universitêre musiekopleiding vir subsidiedoeleindes erken mag word nie, wat dringende aandag van die universiteite vereis. Dit maak die een been korter as die ander en strem gevolglik op daadwerklike wys die hele vordring van ons arbeid.

Aangaande die verhouding van kuns tot wetenskap in die opleiding van toekomstige musici hoef daar geen misverstand te heers nie. In die klassiekgeworde definisie van Jevons lui dit: "A science teaches us to know and an art to do". Musiek as wetenskap het betrekking op die kennis van Musiek. Musiek as kuns is primêr verbonde aan musikale aktiwiteite soos komposisie, musiekvoordrag en die blote luister na Musiek. Dit is nie 'n kompartementele indeling in teenoorgestelde opponerende rigtings nie, want kennis en praktyk is in die Musiek in alle opsigte komplementêr. Die uitvoerende kuns berus op musiekwetenskaplike fondamente en omgekeerd vereis wetenskaplike arbeid die sensiticwe, artistieke reaksies en gevormde intuïsie wat voortvloei uit volgehoue praktiese studies. 'n Furtwängler word gehuldig as dirigecrkunstenaar van groot formaat, veral omdat kennis en kuns in hom in so 'n hoë mate geïntegreer was. Hy het nie slegs beskik oor hoog ontwikkelde gawes van intuïtiewe begrip en inhoudsdeurskouing nie, maar kon hom voortdurend beroep op 'n omvattende, deeglik geassimileerde kennis van die akoestiese en tegnicse hoedanighede van orkestrale instrumente en van teoretiese handwerksvakke soos Harmonie, Kontrapunt en Orkestrasie, sowel as van die historiese en geestelike milieu waaruit die kunswerk ontstaan het. Omgekeerd sou geen navorser op grond van wetenskaplike kundigheid alleen die redigering van ' $n$ ongepubliseerde $17 \mathrm{e}$-eeuse manuskrip kon behartig nit. Selfs die realisering van die volgbas plaas hom voor probleme van klankeffek wat net opgelos kan word deur sensitiewe aanvoeling en 'n innerlike gehoor, geskool in die praktyk. Nog meer, wetenskap en kuns is van die begin af aan saamgesmelt in ' $n$ hoëre eenheid. Daar kan geen Musiek sonder 'n sisteem van toonverhoudings wees nie en geen instrumentebou sonder ten minste proefondervindelike kennis van die akoestiese hoedanighede van pype, snare en resonansruimtes nie. Dit kan as aksiomaties aanvaar word dat die twee studierigtings komplementêr en in die musiekopvoeding samehorig is.

1) Jevons, W. S., Elementary Lessons in Logic, New York 1914, p. 7. 
In verband met die aard, omvang en sistematisering van wetenskap en kuns, moet daar deeglik rekening gehou word met die bekwaamhede en voorkennis van die studentemateriaal wat hulle vir musiekstudie aanmeld. Die standaard is onder eerstejaarstudente veels te laag en speel 'n vername rol in die bepaling van universitêre standaarde. Hiervoor is verskillende omstandighede verantwoordelik waarvan die vernaamste hier net genoem kan word: die halfhartigheid en gebrekkigheid van die skoolmusiekleerplanne, die knellende tekort aan behoorlik opgeleide leerkragte om definitiewe rigting aan die skoolmusiek te gee, die sisteem van individuele onderrig wat gerig is op eksamenresultate in plaas van musikale vorming in breëre sin, en die vry algemene gebrek, veral op die platteland, aan 'n aktiewe gemeenskapsbeoefening van die kuns. Hieroor kan daar breedvoerig uitgewei word, maar dit val buite die bestek van die artikel Van groot belang is op die oomblik slegs dit: dat die tipiese eerstejaarstudent feitlik sonder uitsondering pianis is, dat sy hele kennis van Musiek beperk is tot 'n handjievol klaviermusiek geput uit die agtiende en negentiende eeu, dat hy nouliks kan onderskei tussen polifonie en harmonie en dat sy kennis van die wordingsprosesse, selfs van die stukke wat hy speel, totaal onbenullig is. Hierdie feite speel hulle rol in die bepalings van universitêre musiekstandaarde. Die werksaamhede moet so ingerig word dat die hele voorgraadse studie geskoei is op die lees van 'n breë oriënteringskursus. Idealistiese verhoging van universitêre standaarde sou in die beginstadium so eliminerend werk dat die universiteite nie aan hulle roeping sal voldoen om aan die nasionale behoefte aan musiekopvoedkundiges te voorsien nie. Om dieselfde rede word drie jaar vir die duur van hierdie inleidende studie as voldoende beskou. Op die fondamente gelê in die voorgraadse studie moet dan egter ten minste een jaar nagraadse studie volg, wat van gespesialiseerde aard kan wees. Dit kan gewy word aan musiekopvoedkunde, musiekwetenskap in enger sin, of aan musiekvoordrag met die oog op 'n moontlike professionele loopbaan as pianis, violis of wat ook al. Die inhoud van hierdie studies kan gerieflikerwys opgesom word:

A. Voorgraadse Studie.

1. Praktiese Musiek: solistiese, ensemble-, koor-en orkeswerk.

2. Handwerktuigkundige Vakke: Tearetiese beginsels, Harmonie, Kontrapunt, Instrumentasie, Orkestrasie, Struktuur van Musick. In al hierdie vakke val die klem eers op die studie van tegniek en dan op die verwerwing van tegniek. 
3. Musiekgeskiedenis, met die klem op deeglike oriêntering en intieme kennismaking met die literatuur van die vak deur middel van persoonlike declname, grammofoonplate en partituurlees.

B. Nagraadse Studie.

1. Intensiewe bestudering van die metodiek van individuele onderrig en klasmusiekonderwys. OF

2. Sistematiese Musiekwetenskap. OF

3. Intensiewe praktiese studie, insluitende Komposisie.

Uit akademiese oogpunt gesien, is dit wenslik dat die verkryging van 'n Honneurs- of Magistersgraad gebaseer word op 'n kombinering van 2. en 3. in die een of ander aanneemlike verhouding. In die praktyk sal die student wat Musiek studeer ter wille van die Musiek self, waarskynlik volstaan met die driejarige studie, terwyl die toekomstige professionele inusiekonderwyser nog een jaar professionele opleiding ontvang en die toekomstige musiekwetenskaplike begin met die werk wat eindelik lei tot die verwerwing van die doktorsgraad.

Benewens die professionele opleiding hierbo geskets moet die universitêre Musiekdepartement ook nog voorsiening maak vir die redelik wyc belangstelling wat daar onder B.A.-, B.Ss.- en ander studente vir die vak heers. Om aan hulle behoeftes te voorsien, moet al die vakke hierbo genoem gereduseer word tot 'n formaat wat pas in die kader van vakke voorgeskryf vir die betrokke graad.

'Ten slotte moet hier nog die voorbereiding vir 'n diploma as kerkorrelis of as musiekonderwyser genoem word. Dit het gebruiklik geword dat universiteite ook hierdie soort opleiding behartig, grotendeels omdat hulle in hoofsaak nog die enigste instansies met fasiliteite vir sodanige opleidin:" is. Waarskynlik sal hierdie driejarige opleidings ook nog in die toekonıs 'n funksie van die Universiteite bly. Dit moet egter gestel word, dat 'n akademiese Musiekdepartement in die eerste instansie verantwoordelik is vir die voorbereiding van graadstudente. Die regverdiging vir diplomaopleiding kan slegs geskied op grond van die landswye nood aan musiekonderwysers en orreliste, wat ons noodsaak om ook persone wat nie aan universitêre toelatingsvereistes voldoen nie, te aanvaar. Diplomaopleiding loop parallel met die graadopleiding hierbo geskets, maar net op 'n laer peil, en sonder die moontlikheid van 'n erkende voortsetting van studies in 'n vierde jaar. 
Wanneer 'n mens nou in gedagte hou dat dit steeds weer dieselfde personeel is wat jaar na jaar hierdie wydvertakte pligte moet nakom en dat die personeel aan al die universiteite veels te klein is vir die omvang van die werk, sodat elkeen gereëld twee tot drie aspekte van die kuns op universitêre standaard moet doseer, dan is dit duidelik dat die musiekdoserendes in ' $n$ uiters ongunstige posisie verkeer, nie net in vergelyking met hulle oorsese kollegas nie, maar ook vergelykenderwys met hulle kollegas in ander Universiteitsdepartemente. Die S.-A. musiekdosent staan vas in sy pedagogiese tuig en kan slegs verlangende blikke werp op die menigvuldige, wydvertakte weë van die vak wat hy selde of ooit kan betree. Kunstenaars-, skeppings- en navorsingsaktiwiteite moet noodgedwonge agterweë bly, of ternouernood ingepas word. Dit is 'n aspek van ons universitêre musickopvoeding wat crnstige aandag verdien. Terwyl die vakbiblioteke in Afrikaans oral met handleidings, monografieë en ander publikasies verryk word, toon dic Musiek weinig of geen vordering nie. Die vakmanne is alınal deur personeeltekort aan bande gelê.

Jit is in die loop van hierdic artikel herhaaldelik beklemtoon dat daar in die musiekprofessie 'n groot agterstand in die voorsienng van greskikte leerkragte heers. Ons kan nie voorsien aan die behocftes wat voortdurend deur Kerk, Skool en privaatgemeenskappe aan ons gestel word nie. In oorecnstemming met die aanvraag is die geleenthede vir jong musici menigvuldig en ryk aan belofte. Daar was 'n tyd toe afgestudeerde skoolonderwysers feitlik werkloos was en toe Musiek in Suid-Afrika feitlik net deur dames beoefen is. Ouers was in die reel huiwerig om kinders, hoe begaafd ook al, in dié rigting te laat ontwikkel. Tans heers daar, net soos in die skoolonderwys, 'n knellende tekort aan opgeleide leerkragte in Musiek. Daar hoef geen bedenkinge meer te bestaan oor die wenslikheid om begaafde kinders Musiek as professie te laat kies nie.. Trouens, dit het 'n dure plig geword om almal wat oor die nodige aanleg beskik in diens van die kuns te stcl, want daarmee word 'n diens bewys aan 'n maatskappy wat hier, soos elders, dreig om geestelik te disintegreer en in duistere onverskilligheid te verval. Musiekopvoeding beteken verdere verstewiging van die bolwerke teen die duistere magte wat die geestelike kern van die Wes-Europese beskawing bedreig. Die musiekprofessie het in hoë mate nou ook roeping geword.

Dit is ook die gees waarin die universitêre Musiekdepartemente hulle roeping wil vervul. 